\title{
Penerapan Model Pembelajaran PASA dalam Meningkatkan Motivasi Belajar pada Pembelajaran Sejarah Kelas X IPS 2 SMAN 1 Barru
}

\section{Application of PASA Learning Model in Increasing Learning Motivation in Learning History Class X IPS 2 SMAN 1 Barru}

\author{
Rezki Auliana ${ }^{1}$, Patahuddin $^{2}$, Bustan $^{3}$ \\ $1 \bowtie 23$ Universitas Negeri Makassar \\ E-mail: rezkiauliana2016@gmail.com ${ }^{\bowtie}$, patahuddin@unm.ac.id, bustan@unm.ac.id
}

Diterima: 30 Januari 2021 | Direvisi: 02 Maret 2021 | Diterbitkan: 31 Maret 2021

\section{ARTICLE INFO}

Keywords:

PASA,

Learning Motivation, History Learning.

\section{Kata Kunci:}

PASA,

Motivasi Belajar,

Pembelajaran Sejarah.
ABSTRACT

\begin{abstract}
This study aims to analyze the application of the implementing the Picture and Student Active (PASA) learning model in increasing learning motivation of learning history in Class X IPS 2 SMAN 1 Barru. This research is a Classroom Action Research using qualitative and quantitative data analysis. This study shows that there are increases in students' historical learning motivation after apply PASA learning model, namely in Cycle I it shows that the average score of students' learning motivation is $67.47 \%$ which is in the medium category, while in Cycle II shows the average score of students' learning motivation of $80.88 \%$ which is in the high category. So, it can be concluded that the application of the PASA learning model can increase the learning motivation of Class X IPS 2 SMAN 1 Barru students.
\end{abstract}

Penelitian ini bertujuan untuk menganalisis penerapan model pembelajaran Picture and Student Active (PASA) dalam meningkatkan motivasi belajar pada pembelajaran sejarah Kelas X IPS 2 SMAN 1 Barru. Penelitian ini adalah Penelitian Tindakan Kelas menggunakan analisis data kualitatif dan kuantitatif. Penelitian ini menunjukkan bahwa terjadi peningkatan motivasi belajar sejarah peserta didik setelah menerapkan model pembelajaran PASA, yaitu pada Siklus I menunjukkan bahwa skor rata-rata motivasi belajar peserta didik sebesar $67,47 \%$ yang berada pada kategori sedang, sedangkan pada Siklus II menunjukkan skor rata-rata motivasi belajar peserta didik sebesar $80,88 \%$ yang berada pada kategori tinggi. Maka, dapat disimpulkan bahwa penerapan model pembelajaran PASA dapat meningkatkan motivasi belajar peserta didik Kelas X IPS 2 SMAN 1 Barru.

\section{PENDAHULUAN}

Pendidikan merupakan bagian integral dalam pembangunan. Proses pendidikan tak dapat dipisahkan dari proses pembangunan itu sendiri. Pembangunan diarahkan dan bertujuan untuk mengembangkan sumber daya manusia yang berkualitas dan pembangunan sektor ekonomi yang satu dengan lainnya saling berkaitan dan berlangsung dengan berbarengan (Malik, 2014).

Pendidikan adalah proses dalam rangka mempengaruhi peserta didik supaya mampu menyesuaikan diri sebaik mungkin dengan lingkungannya. Hal ini dilakukan guna melahirkan sumber daya manusia yang berkualitas dan pengembangan pembangunan sektor ekonomi. Terlebih lagi, apabila dikaitkan 
dengan era Revolusi Industri 4.0 yang saat ini menjadi tantangan berat bagi Indonesia (Absor, Umasih, \& Kurniawati, 2019).

Dalam proses pembelajaran, motivasi merupakan suatu hal yang penting, karena menjadi salah satu faktor yang memengaruhi keberhasilan pembelajaran peserta didik. Sering terjadi peserta didik yang kurang berprestasi bukan disebabkan oleh kemampuannya yang kurang, akan tetapi dikarenakan tidak adanya motivasi untuk belajar, sehingga ia tidak berusaha untuk mengerahkan segala kemampuannya (Nasution, 2016; Sanjaya, 2008; Suyuti \& Ervina, 2020; Uno, 2007).

Motivasi berperan penting dalam proses pembelajaran dan keberhasilan proses belajar itu sendiri. Motivasi lebih banyak ditekankan pada individu peserta didik dengan harapan munculnya semangat untuk mengikuti proses pembelajaran. Motivasi yang dimiliki peserta didik akan menjadikan peserta didik memiliki semangat, disiplin, tanggung jawab, dan keseriusan mengikuti proses pembelajaran. Dengan kata lain, peran motivasi dalam proses pembelajaran peserta didik tidak lain sebagai sumber energi psikologis.

SMAN 1 Barru merupakan salah satu Sekolah Menengah Atas Negeri yang ada di Kabupaten Barru, Provinsi Sulawesi Selatan. Peneliti mengawalinya dengan melakukan observasi pada salah satu kelas yang ada di SMAN 1 Barru, yakni Kelas X IPS 3 yang berjumlah 32 peserta didik. Observasi ini dilakukan dari tanggal 10 Oktober 2019 sampai tanggal 17 Oktober 2019. Berdasarkan observasi peneliti pada kelas tersebut, motivasi belajar peserta didiknya masih terbilang rendah, hal ini terlihat dari masih banyaknya peserta didik yang kurang bersemangat dan jenuh dalam menerima pembelajaran sejarah di kelas. $\mathrm{Hal}$ ini sesuai dengan penelitian yang ada bahwa pembelajaran sejarah dianggap membosankan, tidak menarik, dan susah untuk dipahami (Alfian, 2011; Santosa, 2017; Sayono, 2013). Banyak peserta didik yang cenderung pasif saat proses pembelajaran berlangsung. Hal ini berdampak pada prestasi peserta didik itu sendiri. Oleh karena itu, peran guru dalam pembelajaran sangat penting agar tujuan pendidikan dapat tercapai.

Motivasi belajar yang terbilang rendah di kelas tersebut, dikarenakan model atau metode pembelajaran yang diterapkan kurang menarik. Untuk mengatasi permasalahan pembelajaran tersebut, diperlukan suatu perbaikan pembelajaran. Salah satunya adalah penerapan model pembelajaran yang menarik dan mampu mengaktifkan peserta didik. Dengan peserta didik berperan aktif dalam proses pembelajaran, maka peserta didik dapat mengembangkan pemikiran, ide, dan menemukan konsep pikir yang nyata. Hal ini sangat berpengaruh pada motivasi belajar peserta didik.

Salah satunya model pembelajaran tersebut adalah Picture and Student Active (PASA). Penelitian Nurhanuddin (2016) menyebutkan bahwa penerapan metode pendekatan Contextual Teaching Learning dengan model PASA dipercaya sebagai metode yang ampuh dalam meningkatkan motivasi belajar siswa dalam mata pelajaran Sejarah. Selain itu, penelitian Setyastuti (2017) menunjukkan bahwa terdapat peningkatan hasil pembelajaran sejarah menggunakan model pembelajaran 
Auliana, Patahuddin, Bustan, 2021, Penerapan Model Pembelajaran. . .

PASA. Penelitian tersebut memiliki relevansi dengan penelitian yang dilakukan oleh peneliti, yaitu menggunakan model pembelajaran PASA.

Model pembelajaran PASA adalah model pembelajaran yang bertujuan membantu peserta didik untuk memahami makna materi ajar dengan menggunakan media gambar yang berkaitan terhadap konteks kehidupan mereka sehari-hari (konteks pribadi, sosial dan kultural), sehingga peserta didik memiliki pengetahuan atau keterampilan yang dinamis dan fleksibel untuk mengkonstruksi sendiri secara aktif pemahamannya. Gambar-gambar tersebut dapat membantu peserta didik menyusun bayangan yang terekam di benak mereka untuk kemudian dijadikan sebagai alat dalam berimajinasi tentang peristiwa yang terjadi di masa lalu secara akurat dan jelas (Joebagio, 2017; Ratumanan, 2015). Berdasarkan uraian tersebut, maka peneliti tertarik melakukan penelitian yang bertujuan untuk menganalisis penerapan model pembelajaran PASA dalam meningkatkan motivasi belajar pada pembelajaran sejarah Kelas X IPS 2 SMAN 1 Barru.

\section{METODE}

Penelitian ini adalah Penelitian Tindakan Kelas (PTK) atau disebut juga Classroom Action Research (CAR). Ditelisik lebih jauh, PTK merupakan suatu aplikasi dari penelitian tindakan, namun PTK berfokus pada proses pembelajaran yang berlangsung di ruangan kelas. PTK adalah suatu bentuk penelitian yang bersifat reflektif dengan melakukan tindakan tertentu agar dapat memperbaiki atau meningkatkan praktik pembelajaran di kelas secara lebih profesional (Ali \& Asrori, 2014;
Arikunto \& Suhardjono, 2015; Hendriana, 2017; Sukardi, 2016).

Subjek penelitian adalah peserta didik Kelas X IPS 2 SMAN 1 Barru Semester Ganjil dengan jumlah siswa 23 oarang peserta didik, yakni 9 orang laki-laki dan 14 orang perempuan dengan fokus penelitian, yaitu motivasi belajar sejarah melalui penerapan model pembelajaran PASA. Penelitian ini dilaksanakan di SMAN 1 Barru yang beralamat di Jalan Jenderal Sudirman, Sumpang Binangae, Kecamatan Barru, Kabupaten Barru, Sulawesi Selatan. Pelaksanaan penelitian dilakukan mulai tanggal 22 September 2020 sampai 27 Oktober 2020. Penelitian ini dilaksanakan pada tahun pelajaran 2020/2021. Karena terjadi selama masa pandemi Covid-19, maka peneliti memanfaatkan pembelajaran secara daring menggunakan Zoom dan Whatsapp (Absor, 2020).

Dalam penelitian ini pengumpulan data menggunakan alat pengumpulan data yang sesuai dengan masalah yang diteliti, yakni angket, dokumentasi, dan observasi. Penelitian ini menggunakan dua bentuk analisis data, yaitu analisis kualitatif dan kuantitatif (Sugiyono, 2015). Analisis data kualitatif dalam penelitian ini adalah analisis interaktif yang diperoleh dengan teknik observasi. Sedangkan, data hasil motivasi belajar peserta didik didapat dari analisis secara kuantitatif dengan statistik deskriptif. Pedoman pengkategorian motivasi belajar yang digunakan dalam penelitian ini menggunakan pengkategorian oleh Purwanto (2008) dalam tabel berikut: 
Tabel 1. Format Tabel

\begin{tabular}{|c|c|c|}
\hline No. & Rentang Skor (\%) & Kategori \\
\hline 1 & $\leq 54$ & Sangat Rendah \\
\hline 2 & $55-59$ & Rendah \\
\hline 3 & $60-75$ & Sedang \\
\hline 4 & $76-85$ & Tinggi \\
\hline 5 & $86-100$ & Sangat Tinggi \\
\hline
\end{tabular}

Data angket motivasi belajar peserta didik dianalisis dengan menggunakan rumus Purwanto (2008) sebagai berikut:

$$
\mathrm{NP}=\frac{\mathrm{R}}{\mathrm{SM}} \times 100 \%
$$

Keterangan:

NP : Nilai persentase motivasi belajar peserta didik yang dicari.

$\mathrm{R} \quad$ : Skor total yang diperoleh peserta didik.

SM : Skor maksimal yang mungkin diperoleh.

Untuk melihat besar persentase peningkatan motivasi belajar peserta didik pada penerapan model pembelajaran PASA digunakan ketentuan sebagai berikut:

Persentase Peningkatan = NP Siklus II - NP Siklus I

\section{HASIL DAN PEMBAHASAN}

\section{Siklus I}

a. Perencanaan Tindakan Siklus I

Pada perencanaan Siklus I ini peneliti melakukan beberapa hal di antaranya bertemu dengan guru mata pelajaran sejarah untuk membahas materi yang akan digunakan sebagai bahan penelitian. Selain itu, peneliti menyiapkan berbagai instrumen yang akan digunakan seperti Rencana Pelaksanaan Pembelajaran (RPP), lembar pengamatan, bahan ajar, dan angket.

b. Pelaksanaan Tindakan Siklus I

1) Siklus I Pertemuan Pertama
Pertemuan pertama dilaksanakan pada hari Selasa, 22 September 2020 pada pukul 07.30-08.10 (40 menit pelajaran) dengan pembelajaran daring menggunakan aplikasi Zoom. Pada tahap ini, peneliti menyampaikan pokok-pokok materi tentang manusia dan sejarah. Setelah itu peneliti menjelaskan secara singkat mengenai model pembelajaran yang akan digunakan untuk beberapa pertemuan berikutnya, yaitu model pembelajaran PASA. Peneliti memperlihatkan gambar yang terkait dengan materi, lalu peserta didik diberikan kesempatan untuk menebak gambar tersebut dan memberikan penjelasan terkait gambar tersebut. Pada tahap ini, beberapa peserta didik dapat menebak gambarnya dengan benar, namun tidak semua dari mereka dapat menebaknya dengan benar. Hal ini terjadi karena sebagian besar peserta didik masih bingung atau belum terbiasa dengan model pembelajaran yang diterapkan.

2) Siklus I Pertemuan Kedua

Pertemuan pertama dilaksanakan pada hari Selasa, 29 September 2020 pada pukul 07.30-08.10 (40 menit pelajaran) dengan pembelajaran daring menggunakan aplikasi Zoom. Pada tahap ini, peneliti menyampaikan pokok-pokok materi tentang sejarah sebagai ilmu, peristiwa, kisah, dan seni. Sebelumnya peneliti sudah mengirimkan materi yang akan dibahas pada pertemuan ini melalui grup Whatsapp. Jadi, peneliti hanya menjelaskan secara singkat mengenai 
Auliana, Patahuddin, Bustan, 2021, Penerapan Model Pembelajaran. . .

materinya. Peneliti memperlihatkan gambar yang merupakan contoh dari sejarah sebagai ilmu, peristiwa, kisah, dan seni, lalu peserta didik diberikan kesempatan untuk menebak gambar yang kira-kira contoh dari sejarah sebagai, ilmu, kisah, dan seni. Setiap peserta didik yang ingin menjawab diminta untuk menyebutkan namanya terlebih dadulu agar peneliti dapat mengetahui peserta didik yang aktif. Pada tahap ini, peserta didik mulai antusias untuk dapat menebak atau menjawab gambar yang telah diperlihatkan, walaupun masih ada beberapa yang belum sepenuhnya akif menjawab.

3) Siklus I Pertemuan Ketiga

Pertemuan pertama dilaksanakan pada hari Selasa, 6 Oktober 2020 pada pukul 07.30-08.10 (40 menit pelajaran) dengan pembelajaran daring menggunakan aplikasi Zoom. Pada tahap ini, peneliti menyampaikan pokok-pokok materi tentang cara berpikir diakronik (kronologis). Pada petemuan kali ini, gambar yang diperlihatkan berupa contoh peristiwa Mei 1998 yang tidak berurut. Peserta didik diberi tugas untuk bisa menebak tanggal serta hal yang terjadi pada peristiwa Mei 1998 yang nanti akan diurutkan peristiwanya dari awal terjadinya sampai akhir terjadinya peristiwa Mei 1998 tersebut. Pada tahap ini, peserta didik mulai antusias untuk dapat menebak atau menjawab gambar yang telah diperlihatkan dan mulai termotivasi untuk belajar sejarah.

c. Observasi
Berikut hasil observasi yang dilakukan selama kegiatan pembelajaran pada Siklus I yaitu:

1) Peserta didik yang hadir pada saat pembelajaran berlangsung mencapai $94,17 \%$.

2) Peserta didik yang menyimak pembelajaran sebesar $70,83 \%$.

3) Peserta didik yang mengajukan pertanyaan saat pembelajaran berlangsung sebesar $43,47 \%$.

4) Peserta didik yang antusias mengikuti pembelajaran dengan model PASA sebesar $75,34 \%$.

5) Peserta didik yang melakukan kegiatan lain pada saat pembelajaran berlangsung sebesar $30,43 \%$.

6) Peserta didik yang dapat menjawab pertanyaan-pertanyaan secara lisan yang diberikan oleh guru sebesar $43,47 \%$.

d. Deskripsi Hasil Angket Siklus I

Tabel 2. Distribusi Frekuensi dan Persentase Motivasi Belajar Peserta Didik pada Siklus I

\begin{tabular}{|c|c|c|c|c|}
\hline No & \begin{tabular}{|c} 
Rentang \\
$(\%)$
\end{tabular} & Kategori & Frekuensi & Persentase \\
\hline 1 & $86-100$ & Sangat Tinggi & 0 & $0 \%$ \\
\hline 2 & $76-85$ & Tinggi & 1 & $4,3 \%$ \\
\hline 3 & $60-75$ & Sedang & 13 & $57 \%$ \\
\hline 4 & $55-59$ & Rendah & 9 & $39 \%$ \\
\hline 5 & $\leq 54$ & $\begin{array}{l}\text { Sangat } \\
\text { Rendah }\end{array}$ & 0 & $0 \%$ \\
\hline \multicolumn{3}{|c|}{ Jumlah } & 23 & $100 \%$ \\
\hline \multicolumn{3}{|c|}{$\begin{array}{c}\text { Skor Total yang } \\
\text { Diperoleh Seluruh Peserta } \\
\text { Didik }\end{array}$} & \multicolumn{2}{|c|}{3104} \\
\hline \multicolumn{3}{|c|}{ Skor Rata-Rata } & \multicolumn{2}{|c|}{$67,47 \%$} \\
\hline
\end{tabular}

e. Refleksì

Pada awal pertemuan Siklus I, khususnya pertemuan pertama, peserta didik masih kelihatan bingung dan kurang memahami model pembelajaran PASA yang diterapkan. Hal ini disebabkan karena model pembelajaran tersebut merupakan suatu hal yang baru bagi peserta didik kelas X IPS 2 
SMAN 1 Barru. Pada pertemuan kedua, sebagian peserta didik sudah mulai beradaptasi dengan model pembelajaran PASA yang diterapkan. Setidaknya hal ini menunjukkan adanya usaha dari peserta didik untuk lebih mengerti dan memahami model pembelajaran yang diterapkan. Pada akhir Siklus I, setiap peserta didik diberikan angket untuk mengetahui tingkat motivasi belajar peserta didik, diketahui bahwa skor rata-rata motivasi belajar peserta didik belum mencapai indikator keberhasilan penelitian yang telah ditetapkan, sehingga penelitian dilanjutkan dengan Siklus II.

\section{Siklus II}

a. Perencanaan Tindakan Siklus II

Pada perencanaan Siklus I sebelumnya masih ada proses pembelajaran yang masih dianggap kurang, maka dilakukan perbaikan pada Siklus II. Pada Siklus II, RPP tetap sama, hanya saja pelaksanaannya akan lebih dimaksimalkan untuk memperbaiki kekurangan yang ada pada Siklus I.

b. Pelaksanaan Tindakan Siklus II

1) Siklus II Pertemuan Keempat

Pertemuan keempat dilaksanakan pada hari Selasa, 13 Oktober 2020 pada pukul 07.30-08.10 (40 menit pelajaran) dengan pembelajaran daring menggunakan aplikasi Zoom. Pada tahap ini, peneliti menyampaikan pokok-pokok materi tentang cara berpikir diakronik. Sama seperti pertemuan sebelumnya peneliti sudah mengirimkan materi yang akan dibahas pada pertemuan ini melalui grup Whatsapp. Peneliti hanya menjelaskan secara singkat mengenai materinya.
Peneliti memperlihatkan gambar yang terkait dengan materi kemudian peserta didik menebak dan menjawab gambar tersebut beserta penjelasannya. Pelaksanaan tindakan pada Siklus II ini secara umum sama dengan Siklus I, hanya saja lebih memonitoring peserta didik agar lebih aktif dan berpikir kritis lagi dalam pembelajaran melalui model pembelajaran PASA.

2) Siklus II Pertemuan Kelima

Pertemuan pertama dilaksanakan pada hari Selasa, 20 Oktober 2020 pada pukul 07.30-08.10 (40 menit pelajaran) dengan pembelajaran daring menggunakan aplikasi Zoom. Pada tahap ini, peneliti menyampaikan pokok-pokok materi tentang sumber sejarah (artefak, fosil, tekstual, nontekstual, kebendaan, visual, audio visual, dan tradisi lisan). Berbeda dari sebelumnya, peneliti tidak mengirimkan materi yang akan dibahas pada pertemuan ini, melainkan peserta didik yang harus mencari dan menemukan materinya. Nanti pada saat peneliti memperlihatkan gambarnya, maka peserta didik akan lebih mudah menebaknya karena peserta didik sudah mencari serta memahami materi tersebut. Hal ini dilakukan agar peserta didik bisa lebih aktif secara keseluruhan. Pada tahap ini juga peserta didik berlomba-lomba untuk bisa menebak dan menjawab karena materi sudah mereka baca dan pahami.

3) Siklus II Pertemuan Keenam 
Auliana, Patahuddin, Bustan, 2021, Penerapan Model Pembelajaran. . .

Pertemuan pertama dilaksanakan pada hari Selasa, 27 Oktober 2020 pada pukul 07.30-08.10 (40 menit pelajaran) dengan pembelajaran daring menggunakan aplikasi Zoom. Pada tahap ini, peneliti menyampaikan pokok-pokok materi tentang cara langkah-langkah penelitian sejarah (heuristik, kritik/verifikasi, interpretasi/eksplanasi, dan historiografi/penulisan sejarah). Sama seperti pertemuan sebelumnya, peneliti sudah mengirimkan materi yang akan dibahas pada pertemuan ini melalui grup Whatsapp. Peneliti hanya menjelaskan secara singkat mengenai materinya. Pada petemuan kali ini, gambar yang diperlihatkan akan dipasangakan atau diurutkan berdasarkan urutannya. Hal ini sedikit berbeda dari sebelumya yang hanya menebak atau menjawab. Pada tahap ini, peserta didik antusias untuk dapat mengurutkan dan menjawab gambar yang telah diperlihatkan.

c. Observasi

Perubahan keaktifan dan aktivitas peserta didik pada Siklus II menuju ke arah yang lebih positif dijabarkan sebagai berikut:

1. Peserta didik yang hadir pada saat pembelajaran berlangsung mencapai $97,86 \%$.

2. Peserta didik yang menyimak pembelajaran sebesar $95,65 \%$.

3. Peserta didik yang mengajukan pertanyaan saat pembelajaran berlagsung mencapai $49,26 \%$.

4. Peserta didik yang antusias mengikuti pembelajaran dengan model PASA sebesar $91,30 \%$.
5. Peserta didik yang melakukan kegiatan lain pada saat pembelajaran berlangsung sebesar $14,47 \%$.

6. Peserta didik yang dapat menjawab pertanyaan-pertanyaan secara lisan yang diberikan oleh guru sebesar $47,82 \%$.

d. Deskripsi Hasil Angket Siklus II

Tabel 3. Distribusi Frekuensi dan Persentase Motivasi Belajar Peserta Didik pada Siklus II

\begin{tabular}{|c|c|c|c|c|}
\hline No. & $\begin{array}{c}\text { Rentang } \\
(\%)\end{array}$ & Kategori & Frekuensi & Persentase \\
\hline 1 & $86-100$ & $\begin{array}{l}\text { Sangat } \\
\text { Tinggi }\end{array}$ & 6 & $26 \%$ \\
\hline 2 & $76-85$ & Tinggi & 9 & $39 \%$ \\
\hline 3 & $60-75$ & Sedang & 8 & $35 \%$ \\
\hline 4 & $55-59$ & Rendah & 0 & $0 \%$ \\
\hline 5 & $\leq 54$ & $\begin{array}{l}\text { Sangat } \\
\text { Rendah }\end{array}$ & 0 & $0 \%$ \\
\hline \multicolumn{3}{|c|}{ Jumlah } & 23 & $100 \%$ \\
\hline \multicolumn{4}{|c|}{$\begin{array}{l}\text { Skor Total yang Diperoleh Seluruh } \\
\text { Peserta Didik }\end{array}$} & 3684 \\
\hline \multicolumn{4}{|c|}{ Skor Rata-Rata } & $80,88 \%$ \\
\hline
\end{tabular}

e. Refleksi

Pembelajaran yang dilakukan pada Siklus II ini merupakan tindakan tindakan perbaikan dari pembelajaran Siklus I. Rangkaian kegiatan pada Siklus II mulai dari perencanaan, pelaksanaan tindakan, observasi hingga refleksi mengalami kemajuan positif. Setelah melakukan perbaikan, berdasarkan hasil observasi dan evaluasi selama proses pembelajaran berlangsung dapat dinyatakan bahwa motivasi belajar meningkat serta aktivitas peserta didik menjadi lebih positif. Peningkatan motivasi belajar sejarah peserta didik Kelas X IPS 2 SMAN 1 Barru dapat dilihat dari tabel berikut ini. 
Tabel 4. Perbandingan Frekuensi dan Persentase Motivasi Belajar Peserta Didik pada Siklus I dan Siklus II

\begin{tabular}{|c|c|c|c|c|c|}
\hline $\begin{array}{c}\text { Rentang } \\
(\%)\end{array}$ & \multicolumn{2}{|c|}{ Siklus I } & \multicolumn{2}{c|}{ Siklus II } & Kategori \\
\hline & Frekuensi & $\begin{array}{c}\text { Persentase } \\
(\%)\end{array}$ & Frekuensi & $\begin{array}{c}\text { Persentase } \\
(\%)\end{array}$ & \\
\hline $86-100$ & 0 & $0 \%$ & 6 & $26 \%$ & $\begin{array}{c}\text { Sangat } \\
\text { Tinggi }\end{array}$ \\
\hline $76-85$ & 1 & $4,3 \%$ & 9 & $39 \%$ & Tinggi \\
\hline $60-75$ & 13 & $57 \%$ & 8 & $35 \%$ & Sedang \\
\hline $55-59$ & 9 & $39 \%$ & 0 & $0 \%$ & Rendah \\
\hline$\leq 54$ & 0 & $0 \%$ & 0 & $0 \%$ & $\begin{array}{c}\text { Sangat } \\
\text { Rendah }\end{array}$ \\
\hline Jumlah & $\mathbf{2 3}$ & $\mathbf{1 0 0} \%$ & $\mathbf{2 3}$ & $\mathbf{1 0 0} \%$ & \\
\hline & Rata-rata & $\mathbf{7 0 , 7 0 \%}$ & Rata-rata & $\mathbf{8 0 , 8 8 \%}$ & \\
\hline
\end{tabular}

Selain terjadi peningkatan motivasi belajar peserta didik, proses pembelajaran yang berjalan selama 2 siklus ini menunjukkan adanya perubahan keaktifan dan aktivitas peserta didik. Perubahan tersebut dapat dilihat dari hasil observasi yang dilakukan pada setiap pertemuan pada Siklus I dan Siklus II. Perubahan keaktifan dan aktivitas peserta didik tersebut antara lain:

1. Peserta didik yang hadir saat pembelajaran berlangsung mengalami peningkatan pada Siklus I 94,17\% menjadi $97,86 \%$ pada Siklus II.

2. Peserta didik yang menyimak pembelajaran meningkat dari $70,83 \%$ pada Siklus I menjadi $95,65 \%$ pada Siklus II.

3. Peserta didik yang mengajukan pertanyaan saat pembelajaran berlangsung juga mengalami peningkatan, yakni pada Siklus I sebesar 43,47\% menjadi $49,26 \%$ pada Siklus II.

4. Peserta didik yang antusias mengikuti pembelajaran dengan model pembelajaran PASA meningkat yang awalnya hanya $75,34 \%$ pada Siklus I menjadi $91,30 \%$ pada Siklus II.

5. Peserta didik yang melakukan kegiatan lain pada saat pembelajaran berlangsung mengalami penurunan dari $30,43 \%$ pada Siklus I menjadi $14,47 \%$ pada Siklus II.

6. Peserta didik yang dapat menjawab pertanyaan-pertanyaan secara lisan yang diberikan oleh guru juga meningkat dari $43,47 \%$ pada Siklus I menjadi $47,82 \%$ pada Siklus II.

Sehingga, dapat dideskripsikan bahwa hasil angket motivasi belajar sejarah peserta didik Kelas X IPS 2 SMAN 1 Barru pada Siklus I bahwa dari 23 peserta didik yang mengisi angket pada Siklus I, skor total angket yang diperoleh dari peserta didik sebanyak 3.104 dari skor maksimal 4.600 dan menghasilkan nilai rata-rata $67,47 \%$, hal ini berada pada kategori sedang. Sedangkan hasil angket motivasi belajar sejarah peserta didik pada Siklus II menunjukkan skor total angket yang diperoleh dari peserta didik sebanyak 3.684 dari skor maksimal 4.600 dan menghasilakan nilai ratarata $80,88 \%$, hal ini berada pada kategori tinggi.

Perubahan keaktifan dan aktivitas peserta didik ke arah positif ini menunjukkan adanya keinginan peserta didik untuk lebih aktif dalam belajar. Hal ini membuat peserta didik menjadi termotivasi dan semangat dalam belajar. Sehingga penerapan model pembelajaran PASA di Kelas X IPS 2 SMAN 1 Barru menunjukkan adanya peningkatan motivasi belajar peserta didik terhadap pembelajaran sejarah.

Dari Siklus I dan Siklus II dapat dilihat bahwa model pembelajaran PASA adalah model pembelajaran yang bertujuan membantu peserta didik untuk memahami makna materi ajar dengan menggunakan media gambar yang berkaitan terhadap konteks kehidupan mereka sehari-hari (konteks pribadi, sosial dan kultural), 
Auliana, Patahuddin, Bustan, 2021, Penerapan Model Pembelajaran. . .

sehingga peserta didik memiliki pengetahuan atau keterampilan yang dinamis dan fleksibel untuk mengkonstruksi sendiri secara aktif pemahamannya.

Konsep utama dari PASA adalah know how to know (mengetahui bagaimana harus mengetahui). Dengan demikian, muncul suatu pernyataan bahwa 'siswa akan lebih mudah memahami gambar peristiwa sejarah daripada membaca, tetapi tanpa membaca akan sulit mendeskripsikan gambar'. Diberikannya materi pelajaran dengan metode yang bervariatif dan penyajian pembelajaran sejarah model PASA diharapkan dapat meningkatkan minat, menumbuhkan kreativitas, kemampuan memberikan jawaban, dan pendapat yang argumentatif. Harapan tersebut akan dapat dicapai secara efektif apabila adanya keterlibatan seluruh komponen pembelajaran yang tepat.

Tujuan pembelajaran dirumuskan sedemikian rupa sesuai dengan kurikulum dan kebutuhan kehidupan siswa. Tujuan pembelajaran yang mampu mengembangkan kompetensikompetensi yang ada pada diri peserta didik. Penyajian materi yang seimbang antara materi pengembangan pengetahuan (kognitif), sikap (afektif), dan keterampilan (psikomotor).

\section{KESIMPULAN}

Berdasarkan uraian di atas, maka dapat disimpulkan bahwa motivasi belajar peserta didik Kelas X IPS 2 SMAN 1 Barru mengalami peningkatan setelah menggunakan model pembelajaran PASA. Hal ini dapat dilihat dari perolehan hasil angket peserta didik dan hasil observasi aktivitas peserta didik selama penelitian. Melalui model pembelajaran ini, peserta didik lebih bersemangat untuk mengikuti pembelajaran sejarah dan merasa senang saat menerima materi, sehingga motivasi belajar mereka akan terus mengalami peningkatan.

\section{DAFTAR PUSTAKA}

Absor, N. F. (2020). Pembelajaran Sejarah Abad 21: Tantangan dan Peluang dalam Menghadapi Pandemi Covid-19. CHRONOLOGIA, 2(1), 30-35.

Absor, N. F., Umasih, U., \& Kurniawati, K. (2019). Pembelajaran Sejarah di SMK Era Revolusi Industri 4.0: Tantangan dan Peluang. Jurnal Teori Dan Praksis Pembelajaran IPS, 4(2), 59-65. https://doi.org/10.17977/um022v4i22019p 059

Alfian, M. (2011). Pendidikan Sejarah Dan Permasalahan Yang Dihadapi. Jurnal Ilmiah Kependidikan, 3(2), 1-8. https://doi.org/10.30595/jkp.v3i2.643

Ali, M., \& Asrori, M. (2014). Metodologi dan Aplikasi Riset Pendidikan. Jakarta: Bumi Aksara.

Arikunto, S., \& Suhardjono, S. (2015). Penelitian Tindakan Kelas Edisi Revisi. Jakarta: Bumi Aksara.

Hendriana, H. (2017). Langkah Praktis Penelitian Tindakan Kelas Bagi Guru. Bandung: Rajawali Pers.

Joebagio, H. (2017). Model-Model Pembelajaran Sejarah di Sekolah Menengah. Jakarta: Rajawali Pers.

Malik, O. (2014). Kurikulum dan Pembelajaran. Jakarta: Bumi Aksara.

Nasution, S. (2016). Interaksi dan motivasi belajar mengajar. Jakarta: Rajawali Pers.

Nurhanuddin. (2016). Peningkatan Motivasi dan Hasil Belajar Siswa pada Pelajaran Sejarah Kelas X SMA Negeri 2 Bulukumba melalui Pendekatan Contextual Teaching and Learning (CTL) dengan Model Pictures and Student Active (PASA). Universitas Negeri Makassar.

Purwanto, M. N. (2008). Prinsip-Prinsip dan Teknik Evaluasi Belajar. Bandung: Remaja Rosdakarya.

Ratumanan. (2015). Inovasi Pembelajaran: 
Mengembangkan Kompetensi Peserta Didik Secara Optimal. Yogyakarta: Ombak.

Sanjaya, W. (2008). Kurikulum Dan Pembelajaran (Teori \& Praktek KTSP). Kencana.

Santosa, Y. B. P. (2017). Problematika Dalam Pelaksanaan Pendidikan Sejarah Di Sekolah Menegah Atas Kota Depok. Jurnal Candrasangkala Pendidikan Sejarah, 3(1), 30. https://doi.org/10.30870/candrasangkala.v 3i1.2885

Sayono, J. (2013). Pembelajaran Sejarah di Sekolah: Dari Pragmatis Ke Idealis. Sejarah Dan Budaya: Jurnal Sejarah, Budaya, Dan Pengajarannya, 7(1), 9-17. Retrieved from http://journal.um.ac.id/index.php/sejarahdan-budaya/article/view/4733

Setyastuti, R. (2017). PENERAPAN METODE PaSA ON BOARD STORIES AND PICTURE STORIE PADA PEMBELAJARAN SEJARAH DI SEKOLAH MENENGAH KEJURUAN. Jurnal IImiah Pro Guru, 3(4), 461-471.

Sugiyono. (2015). Metode Penelitian Pendidikan (Pendekatan Kuantitatif, Kualitatif, dan $R \& D)$. Bandung: Alfabeta.

Sukardi. (2016). Metodologi Penelitian Pendidikan: Kompetensi dan Praktiknya. Jakarta: Bumi Aksara.

Suyuti, S., \& Ervina, E. (2020). Pengaruh Motivasi terhadap Hasil Belajar Sejarah di SMAN 1 Palu. Jurnal Kreatif Online, 8(1), 145-152.

Uno, H. B. (2007). Teori Motivasi dan Pengukurannya: Analisis di Bidang Pendidikan. Jakarta: Bumi Aksara. 